\title{
Simultaneous 3D left and right coronary artery vessel wall imaging
}

\author{
Andrew D Scott ${ }^{1 *}$, Jennifer Keegan ${ }^{2}$, David N Firmin ${ }^{1}$ \\ From 2011 SCMR/Euro CMR Joint Scientific Sessions \\ Nice, France. 3-6 February 2011
}

\section{Objective}

To perform 3D imaging of the left and right coronary vessel walls in a single interleaved acquisition.

\section{Background}

Vessel wall imaging is commonly gated to alternate $\mathrm{R}$-waves, in order to increase SNR and minimise artefacts due to RR-interval variation. In previous work with 2D carotid artery wall imaging, the resulting redundant RR-interval has been used to acquire additional parallel slices[1]. We postulate that the redundant RR-interval can be used to image an additional volume in 3D coronary artery wall imaging. In conjunction with highly efficient beat-to-beat respiratory motion correction (B2B-RMC)[2], this could allow high resolution 3D acquisitions of both the left and right coronary walls in $\sim 10$ minutes.

\section{Methods}

A free-breathing 3D spiral coronary artery wall imaging sequence was modified in order to acquire two high resolution $3 \mathrm{D}$ volumes $(0.7 \times 0.7 \times 3 \mathrm{~mm}$ resolution, 8 slices (reconstructed to $16 \times 1.5 \mathrm{~mm}$ ), acquisition duration 600 cardiac cycles assuming $100 \%$ respiratory efficiency). The first and second volumes were imaged on odd and

even cardiac cycles respectively (figure 1). The slab selective dark blood preparation was modified to reinvert two slabs every cardiac cycle. Respiratory motion compensation was performed independently for each artery using retrospective B2B-RMC which has a respiratory efficiency of nearly $100 \%$ [2],[3].

Acquisitions were performed in healthy subjects using a Siemens Avanto 1.5T scanner. The first and second volumes were positioned to obtain crosssectional left and right coronary images respectively. The first reinversion slab was positioned to selectively reinvert the left coronary artery whilst avoiding reinversion of aortic blood and minimising reinversion of the tissue imaged in the right coronary artery volume. The second reinversion slab was similarly positioned for the right coronary artery. Inversion time was $400 \mathrm{~ms}$ which is optimal for single R-wave gating at 60beats/minute.

\section{Results}

Left and right coronary artery wall images obtained simultaneously in 629 cardiac cycles are shown in figure 2 . The respiratory efficiency was $95 \%$. Image quality, respiratory motion compensation and blood suppression is good in both arteries.
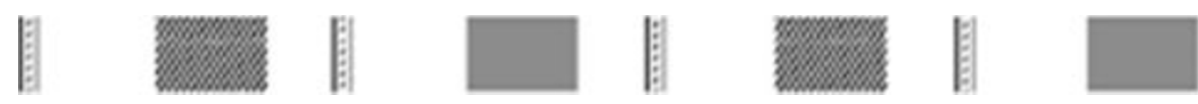

Figure 1 Schematic diagram of the simultaneous left and right 3D coronary vessel wall imaging sequence. In each cardiac cycle, the dark blood preparation non-selectively inverts all tissue and selectively reinverts tissue slabs covering the left and right coronary arteries. Left and right coronary artery wall data are acquired on odd and even cardiac cycles respectively. Each imaging block includes the acquisition of a low resolution 3D fat-excitation dataset which is used to track respiratory motion for B2B-RMC [2].

${ }^{1}$ Imperial College London, London, UK

Full list of author information is available at the end of the article

C Biomed Central

(c) 2011 Scott et al; licensee BioMed Central Ltd. This is an open access article distributed under the terms of the Creative Commons Attribution License (http://creativecommons.org/licenses/by/2.0), which permits unrestricted use, distribution, and reproduction in any medium, provided the original work is properly cited. 


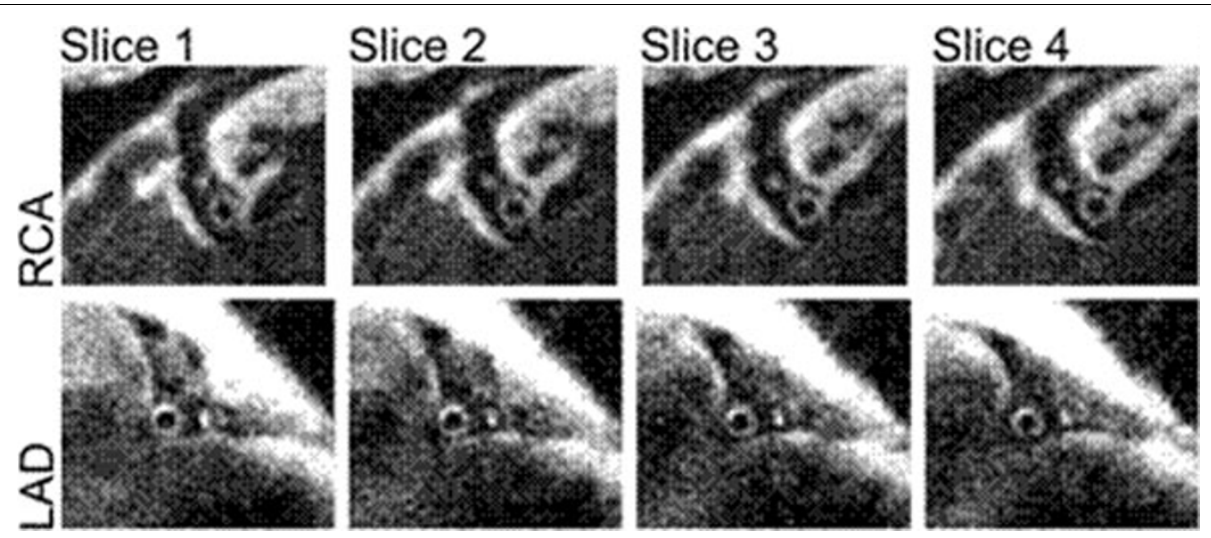

Figure 2 Four contiguous slices from the right (top) and left (bottom) coronary artery volumes acquired simultaneously in 629 cardiac cycles using a dark blood 3D spiral acquisition with B2B-RMC. The respiratory efficiency was $95 \%$.

\section{Conclusions}

We have demonstrated simultaneous left and right coronary artery wall imaging in the duration required to image a single artery. Used in conjunction with B2BRMC, this has permitted high resolution 3D imaging of both the left and right coronary walls in approximately 10minutes. Future work will include a comparison with conventional alternate $\mathrm{R}$-wave gating acquisitions and an investigation of the robustness of the technique to changes in RR interval.

\section{Author details}

${ }^{1}$ Imperial College London, London, UK. ${ }^{2}$ The Royal Brompton and Harefield NHS Foundation Trust, London, UK.

Published: 2 February 2011

\section{References}

1. Parker: MRM 2002.

2. Keegan: JMRI 2007.

3. Scott: JMRI.

doi:10.1186/1532-429X-13-S1-P239

Cite this article as: Scott et al:: Simultaneous 3D left and right coronary artery vessel wall imaging. Journal of Cardiovascular Magnetic Resonance 2011 13(Suppl 1):P239.
Submit your next manuscript to BioMed Central and take full advantage of:

- Convenient online submission

- Thorough peer review

- No space constraints or color figure charges

- Immediate publication on acceptance

- Inclusion in PubMed, CAS, Scopus and Google Scholar

- Research which is freely available for redistribution 